\title{
A Witty Stratagem for Love and Marriage: Oliver Goldsmith's She Stoops to Conquer, or the Mistakes of a Night
}

\author{
Oliver Goldsmith'in She Stoops to Conquer, or the Mistakes of a Night Adlt \\ Oyununda Aşk ve Evlilik İçin Zekice Bir Hile
}

\begin{abstract}
Kübra VURAL ÖZBEY*
Abstract: The plays of a comedy of manners, a genre which emerged in the Restoration period, draw attention through the presentation of colourful couples and pairs, set-scenes, the satirical approach to upper-class manners and certain themes such as material pursuit and a cynical attitude towards love and marriage. This type of comedy, however, met severe critical remarks after the Restoration, as its moral context was questioned as a result of social, economic and governmental changes in the country. Effectively, the second half of the $18^{\text {th }}$ century is laced with the rise of sentimental ideals in that sentimentalism formed the core of the works of the time. Oliver Goldsmith (1728-1774) is one of the literary figures who dwelt upon the new dynamics of the age, and he adapts the conventions of the comedy of manners to his new reader/audience in his play entitled She Stoops to Conquer, or the Mistakes of a Night (1773). While he touches upon the themes of materialism, love, and marriage, he unfolds the idea of parental consent and the quest for true love and affection among the young generation. This propounds the view that the characteristics of the Restoration comedy of manners are metamorphosed in Goldsmith's age, and the playwright uses and abuses sentimental ideas, although he does not challenge the social norms by means of his characters. This paper sets out to determine the contexts of love and marriage in Goldsmith's age that he affirms in the relationships between parental figures and children and in the affairs of couples in She Stoops to Conquer while this play's differences from the Restoration comedy of manners are emphasised.
\end{abstract}

Keywords: Comedy of Manners, Sentimentalism, Love, Marriage, Oliver Goldsmith, She Stoops to Conquer, or the Mistakes of the Night

Öz: Restorasyon döneminde bir tür olarak ortaya çıkan töre komedisi oyunları aşık çiftleri, türe özgü sahneleri, üst sınıf davranışlarına olan hicivsel yaklaşımı, maddi arayış, aşk ve evliliğe karşı kuşkucu yaklaşım gibi temalarıyla dikkat çeker. Ancak töre komedisi, ülkedeki sosyal, ekonomik ve politik değişikliklerin göstergesi olarak ahlaki içeriği bakımından sorgulanınca, Restorasyon döneminden sonra sert eleştirel görüşlere maruz kalır. Özellikle 18. yüzyılın ikinci yarısı duygusal ülkülerin yükselişine tanıklık eder; şöyle ki, duygusallık dönem eserlerinin temelini oluşturur. Oliver Goldsmith (1728-1774) çağının yeni dinamiklerinin üzerine kafa yormuş edebi kişilerden biridir ve She Stoops to Conquer, or the Mistakes of a Night (1773) adlı oyununda Restorasyon dönemi töre komedisi özeliklerini yeni okuyucusu/izleyicisine uyarlar. Oyun yazarı, materyalizm, aşk ve evlilik temalarına değinirken aile onayı kavramını ve genç nesilde gerçek aşk ve yakınlık arayışını göz önüne serer. Bu ise Restorasyon töre komedisi özelliklerinin Goldsmith'in zamanında değiştiğini gösterir. Karakterleri aracılığıyla toplumsal yapıyı sorgulamamasına rağmen, oyun yazarı duygusal fikirleri kullanır ve onları suistimal eder. Bu çalışma, She Stoops to Conquer adlı oyunun Restorasyon töre komedisinden farklılıklarını vurgularken, oyundaki ebeveynler ve çocukları arasındaki ilişkilerde ve aşı çiftlerin ilişkilerinde Goldsmith'in kendi dönemindeki aşk ve evlilik kavramlarını nasıl değerlendirdiğini saptamayı amaçlar.

Anahtar sözcükler: Töre Komedisi, Duygusallık, Aşk, Evlilik, Oliver Goldsmith, She Stoops to Conquer, or the Mistakes of the Night

*Arş. Gör., Hacettepe Üniversitesi, Edebiyat Fakültesi, İngiliz Dili ve Edebiyatı Bölümü, Ankara. vural.kubra@gmail.com 
After the return of Charles II (1630-1685) to his kingdom in 1660, the theatres were reopened by the king, because the Puritan ideology of the Interregnum period banned the performances of plays in theatres from 1642 to 1660 . As a public art form, theatres became important tools to subvert Puritan norms and restrictions since the plays with the support of the restored monarchy were primarily written to entertain the king and his court coming from France. Initially, the plays of earlier playwrights such as William Shakespeare (1564-1616), Ben Jonson (15721637), Francis Beaumont (1584-1616) and John Fletcher (1579-1625) were performed immediately after the restoration of the monarchy in 1660 (Krutch 1961, 14). Meanwhile, some new plays were written: John Tatham's (1632-1664) The Rump (1660), Abraham Cowley's (1618-1667) Cutter of Coleman Street (1661), John Wilson's (1626-1696) The Cheats (1663), John Dryden's (1631-1700) The Wild Gallant (1663), George Etherege's (1636-1691) The Comical Revenge (1664) and Sir Robert Howard's (1626-1698) The Committee (1665) were among the first examples of new plays that were staged in the theatres (Bywaters 2009, 259, Krutch 1961, 14-5).

As the playwrights were supported by Charles II and his court, the plays enacted - mainly comedies to appeal to the taste of the king - were "characterized by [their] relation to social and political change" (Burns 1987, 1), reflecting the life style and fashion of the court and supporting the royalist cause. Therefore, these comedies were based upon the representation of the manners and behaviour of the upper classes and they provide precise details concerning life in London. The playwrights of the Restoration period condemned the parliament supporters, Puritan ideals and despised rural values, in their presentation of aristocratic life. In contrast to the conservative and religious propaganda of the previous government, the dramatists also had a cynical attitude towards the high values of love, marriage, religion and friendship (Montgomery 1966, 40). By addressing a closed community of upper classes, these comedies were welcome by their audience with their light-hearted criticism and witty style.

Signifying that "the Puritan past was past" (Keeble 2002, 180), the reopening of theatres introduced the genre of the comedy of manners with its new type of characters whose features were shaped by the dynamics of the age. Indeed, the characters in these plays were celebrants of the new values of the court of Charles II, such as indulgence, luxury, freedom, sexual pleasure and a fashionable life. In line with the philosophical and political trends of the day Hobbesianism, Epicureanism, skepticism and primitivism or naturalism - the libertine character appeared on the English stage and became a means of purging the previous restrictive ideology. Therefore, the libertine was portrayed as "a power-seeking animal [with] a defiant materialism, a scepticism directed at conventional structures of authority and an egoistic psychology" (Chernaik 1995, 41). Pursuing the pleasures of life by drinking, spending time in the company of friends in the popular places, coffee houses, theatres or parks, flirting or having sex, the libertine character represented the way of life among the members of the upper-class. In this radical opposition to conventional norms of morality and ethics, these libertines not only "rejected the orthodox medieval and Renaissance concept of universal order and of man's place and purpose [but also] embraced the satisfaction of the sense in accordance with the 'reasonable' dictates of Nature - that is [. . .] one's 'natural' impulses and desires" (Underwood 1957, 13). Thus, the plays openly depicted sexual desire and the affairs of the libertines who attempted to achieve "a symbolic enactment of mastery" (Chernaik 1995, 5) through their intercourses.

The libertines' way of living was central to the plays of the time, and their depictions were contrasted with the characters who believed in the ideals of love and marriage. Moreover, the 
bad imitators of the libertines - country bumpkins or fop characters - dominated examples of comedy of manners as they lacked the wit of the libertines in their foolish efforts to follow libertine ideals-fashions. Additionally, the setting, as well as the themes of these plays was determined by the acts of the libertines. While the bedchambers, trendy meeting places - Hyde Park, St. James Park and Covent Garden - and drawing rooms were used as settings, the pursuit of money and sex, adultery, despising country manners and a skeptical attitude towards certain institutions were among the issues addressed through these comedies.

As a case in point, George Etherege's (1636-1692) The Comical Revenge; or, Love in a Tub (1664) is a prototype of the Restoration's comedy of manners plays in which he realistically depicts London city life, represents the nature of libertinism and deals with the set themes of this type of comedy, such as pursuit of sex and money. Sir Frederick is the libertine figure of the play who finds pleasure in drinking, flirting and satisfying his sexual appetite. He is skeptical about love and marriage, and he pursues Mrs. Rich and attempts to deceive her to attain her wealth in his witty plots. On the other hand, he defends Tory idealism and even fights in a duel against the supporters of Cromwell. While Etherege partially pinpoints a heroic aspect for the libertine, his play contains the essential structure of the comedy of manners through its characters, themes and plot. In a similar fashion, William Wycherley (1641-1716), who himself suffered from the practices of the Interregnum period, creates a witty libertine figure, Horner, in his play entitled The Country Wife (1675). The libertine of the play goes after his sexual desires, has affairs with married women and epitomises the hedonistic way of life in his plot to appear to be impotent. His disrespect for the institution of marriage, his hypocrisy and pretense are elaborated in his portrait, and hence the play is based upon intrigues of sexuality, as well as the contradiction between appearence and reality. Applying the conventions of the comedy of manners, the play also alludes to popular activities of London and presents the theatre as a place in which the libertine has an opportunity to carry out his intrigues with a married woman from the country. The Whig husband is cuckolded in Horner's plot as a revenge of the playwright, and the libertine outwits the other characters. Aphra Behn's (1640-1689) The City Heiress (1682) is another example in which the characteristics of the comedy of manners are observed in the depictions of stock character types spending time in the city, themes of material and sexual pursuit, hyprocritical upper-class manners and the intrigues of the plot. The libertine Tom Wilding's cynical approach to marriage, his interest in money and sex and his complex plans to achieve what he desires form the main action of the play whereas his old lecherous uncle is ridiculed owing to his pretense, hypocrisy and Whig politics.

Although such examples were popular on the English stage, Jeremy Collier's (1650-1726) work entitled $A$ Short View of the Immorality and Profaneness of the English Stage Together with the Sense of Antiquity upon This Argument (1698) became a turning point in the history of English drama, when the nature of the Restoration comedy of manners was critically questioned in the light of the example of antiquity. Indeed, the accession of William of Orange (1650-1702) and Queen Mary (1662-1694) in 1688 had already initiated the change on stage, in that libertinism began to lose its significance (Krutch 1961, 153). After their rule, the new era witnessed the rise of the middle class which had a great impact on literary history considering that the plays of the $18^{\text {th }}$ century appealed to the taste of this emerging group in society. Not only the social and economic changes, but also government actions influenced the context and discourse of dramatic works. In particular, the declaration of the Licensing Act in 1737 during George II's (1683-1760) reign diminished the satirical tone of the playwrights, especially in relation to political issues (Simmons 1994, 39). Such changes led to the reformation of the characteristics of the comedy of manners through emphasis on the reward of virtues and 
punishment of vices in the plays of the time.

The comedies which oppossed the libertine ideals, Hobbesian sense of living and the representation of immorality by praising the goodness of human nature, the concepts of virtue, honour, love, and the defeat of vice were called "sentimental comedies." These plays became very popular in the first half of the $18^{\text {th }}$ century (Cox 1969, 2-9). The instructive aim of the literary works came to the fore in this period when Richard Steele's (1672-1729) plays such as The Lying Lover (1703), The Tender Husband (1705) and The Conscious Lovers (1722) dominated the English stage purveying the ideals of sentimental comedy. However, the English stage towards the second half of the $18^{\text {th }}$ century quiescented its previous state in terms of comedy production after the Licensing Act, Quintana claims that "for something like twenty years darkness had descended upon the British comic stage. It was about the time of George III's accession that a new era began, which was to extend through the plays of Sheridan in the 1770 's" $(1965,163)$. The comedies of the first and second decades of the second half of the $18^{\text {th }}$ century were marked not only by Richard Brinsley Sheridan (1751-1816), but also by Oliver Goldsmith (1728-1774).

Born in Ireland, Oliver Goldsmith became a prolific writer of the $18^{\text {th }}$ century who produced works in different genres; he was a playwright, poet, novelist and essayist. Coming from the rural Irish background and observing the different social groups in his journeys, Goldsmith showed a keen eye for social commentary in his works. As a case in point, his novel The Vicar of Wakefield (1766) contextualised economic, social and political conditions of his society within the story of the Primrose family, while his poem The Deserted Village (1770) denounced city life and had a nostalgic mood in the depictions of village life. Goldsmith the playwright was critical, too, questioning in his own way the validity of the dramatic trends of the period. In his first play entitled The Good-Natured Man (1768), for instance, Goldsmith ridiculed and denounced the sentimental comedy by "show[ing] how absurd it could easily become" (Danziger 1978, 22). His critical stance towards popular sentimental plays was also recorded in one of his essays where he analytically scrutinised this type of comedy. In "An Essay on the Theatre" Goldsmith, referring to Aristotle, focused on the differences between tragedy and comedy. He particularly criticised the scenes of weeping in sentimental comedy on the grounds that "comedy should excite our laughter by ridiculously exhibiting the follies of the lower part of mankind" $(1969,751)$. Therefore, what Goldsmith called "weeping sentimental comedy" (1969, 751 ) in this essay fused the elements of tragedy and comedy in a way that the playwright admonished as follows: "If we are permitted to make comedy weep, we have an equal right to make tragedy laugh, and to set down in blank verse the jests and repartees of all the attendants in a funeral procession" $(1969,752)$. Although he criticised sentimental comedy, the spirit of sentimentalism emerged in his works in relation to his dealings with the good nature of mankind and the portraits of the family and love relationships (Wood 2011, 68).

However, when theatres became the domain of powerful managers in the $18^{\text {th }}$ century, Goldsmith suffered from certain problems in staging his plays. For instance, the playwright had to wait for two years for the performance of She Stoops to Conquer, or the Mistakes of a Night (1773) as George Colman (1732-1794), the manager of Covent Garden, was suspicious of the success and profit of Goldsmith's work (Nettleton and Case 1969, 755). Opposing the sentimental trend, Goldsmith somehow revived some previous forms in this play: "Following the tradition of Shakespeare, Ben Jonson, and the English Restoration playwrights of the late seventeenth century, Goldsmith [. . .] delighted in intricate plots, with enough misunderstandings, disguises, mistaken identities, pranks, tests of character, and surprise revelations" 
(Danziger 1978, 17). Yet he stuck to the norms of his period in his thematic concerns of marriage and family relations which were favoured by the audience of his time.

The main action of She Stoops to Conquer is triggered by one major mistake; when Marlow, Sir Charles Marlow's son, and his friend Hastings are on their way to the house of the Hardcastle family to meet Marlow's bride-to-be Kate Hardcastle, they are tricked by Tony Lumpkin, Kate's step-brother. He leads them to the house by convincing two friends that they are in an inn to spend the night as they believe that they get lost. Kate benefits from this deception and disguises herself as the barmaid of the inn because of Marlow's hypocritical attitude towards women. While he plays the role of a shy and timid man among the ladies of his own class, he acts like a rake among the women of lower class. While Kate makes an effort to turn her husband-to-be into a lover for herself, Tony struggles to get rid of the marriage with Constance Neville arranged by his mother Mrs. Hardcastle. Despite his mother's plans for him, Tony enables Neville and her lover Hastings to unite happily in the end. Therefore, the play mainly deals with the theme of arranged marriage in a way that the consent of parental figures is stressed, and the place of love in marriages is underlined. Goldsmith, accordingly, confirms the social norms by dignifying familial ties in his play, although he mocks some sentimental designs. The analysis of Goldsmith's play in this paper sets out to pinpoint the context of love and marriage in his age that the playwright affirms in his depictions of the relationships between parental figures and children and in the affairs of couples in She Stoops to Conquer while the play's differences from the Restoration comedy of manners are highlighted.

Stone argues that after the restoration of the monarchy in 1660, the antagonistic stance against Puritanism "change[d] attitudes towards authority, affection and sex within the middle and upper ranks of society" $(1979,153)$. As the plays of the time exemplified, the libertine figures went after passionate pleasures and questioned the idea of love; more importantly, they objected to the institution of marriage as it would restrict their freedom. However, as Moore claims, the concept of marriage in the $18^{\text {th }}$ century began to change $(2009,8)$. While marriages were still arranged in line with the financial concerns of families in the first half of the $18^{\text {th }}$ century especially among the members of the upper and middle classes, young people started to criticise such arrangements as they were fascinated with the idea of romantic love promoted by the literary works of the time, particularly in sentimental novels (Hitchcook 1997, 27). That is to say, young people began to pursue happiness and freedom in their search for love. As the numbers of those who eloped increased in England, the Marriage Act was declared in 1753 which "stipulated that parental consent was required for couples wishing to marry under the age of 21 " (Moore 2009, 8). Although it was not an easy task to cross class boundaries in marital relationships, there at least grew the sense of "mutual affection" between the couples in the $18^{\text {th }}$ century (Semiday 2015, 11). In line with the changes observed at that time, the representation of love affairs on stage was shaped by the reformed social and moral concerns in that courtship excluded sexual tendencies because "however libertine the eighteenth-century couples [might] appear, the designs of the men [were] honourable and the sentiments of the women [were] innocent" (Butt 1979, 176). Moreover, the ideas of modesty and virtue were put on a pedestal rather than the pursuit of sexual desires in the second half of the $18^{\text {th }}$ century (Sussman 2012, 156-57). From this vantage point, Goldsmith reflected the ideals of his time by restraining the bodily pleasures in love affairs and focusing on the representation of true love in marriages so his play affirmed the institution of marriage and family with his emphasis on romantic love as well as the familial consent in marriage.

The first couple of Goldsmith's play are Mrs. Hardcastle and Mr. Hardcastle who are elderly 
married figures living in the country. Different from the Restoration comedy of manners plays, Goldsmith not only chooses the country for his setting in the play, but also his old characters do not pursue 'unnatural' sexual desires, unlike the stereotypical figures of the Restoration period. Instead, the couple appear to find happiness in their second marriage. However, they have different preferences as indicated in their conversation about the life in the country and the town. Mrs. Hardcastle complains about their life in the country as follows:

Here we live in an old rumbling mansion, that looks for all the world like an inn, but that we never see company. Our best visitors are old Mrs Oddfish, the curate's wife, and little Cripplegate, the lame dancingmaster: And all our entertainment your old stories of Prince Eugene and the Duke of Marlborough. I hate such old-fashioned trumpery (I. 333).

On the other hand, Mr. Hardcastle loves "every thing that's old: old friends, old times, old manners, old books, old wine" (I. 333). Worth comments that "Goldsmith gets fun of this clash of wills, as Congreve and Wycherley had before him" (1992, 93), but, unlike the plays of the previous century, this disagreement does not harm the Hardcastle's marriage.

Compared to her husband, nevertheless, Mrs. Hardcastle is portrayed as a figure of vanity although a woman of her age is supposed to act wisely (Moody 1986, 31). In this regard, she becomes a typical comic figure, as Danziger argues, "[ $\mathrm{t}]$ his type, usually shown in a town environment in English social comedies, becomes even funnier when transposed to the country, where longings to be fashionable seem all the more absurd" (1978, 53). Although she is ridiculed in the scenes where she admires the life in London and attempts to look like a fashionable woman (II. 357), and she is too much concerned with her niece Neville's jewels (III. 366-67), yet Mrs. Hardcastle is depicted as a sensitive parental figure like her husband. While Mr. Hardcastle criticises his step-son Tony for his rakish life style, it is Mrs. Hardcastle who worries about the future of her son as an affectionate mother. For this reason, she tries to exert her authority over her son's life; she hides the fact that Tony is of age to prevent him from controlling his own life, and again it is Mrs. Hardcastle that arranges Tony's marriage with Neville. Albeit her comic caricature and materialistic concern, her maternal side is emphasised in the play in a way that makes this play different from previous examples of comedy of manners in the Restoration period as the character after material pursuit is not a libertine figure, but a caring mother. She once tells Tony that "[i]s this, ungrateful boy, all that I'm to get for the pains I have taken in your education? I that have rock'd you in your cradle, and fed that pretty mouth with a spoon! Did not I work that waistcoast to make you genteel?" (II. 359). That is to say, Mrs. Hardcastle is presented as a devoted mother sacrificing her life for the sake of her son for the time being. Although her material interest and lack of wisdom to comprehend the real intentions of her son make the old woman a blind and foolish mother, her motives are not wicked.

In contrast to his mother's portrait, Tony Lumpkin is drawn as a witty character who subverts the clichéd country man image. He is firstly introduced to the reader/audience as a mischiveous son in the conversation between Mr. Hardcastle and Mrs. Hardcastle. Tony is said to be a man "of tricks and mischief" (I. 334) and have a different sense of humour by "burning the footmen's shoes, frighting the maids, and worrying the kittens" (I. 334) though his mother attempts to provide excuses for her son's naughty actions. While Mrs. Hardcastle wants to turn Tony into an ideal man who will learn Latin in a few years and marry the woman that his mother chooses for him, Tony likes spending his days in the alehouse drinking, singing and dreaming about the time when he will be of age to get rid of his mother's pressure. Therefore, 
he seems to be a kind of rogue figure who goes after his own pleasures. However, it should be noted that Tony is not a stereotypical country person with high aspirations. He neither pursues sex nor money nor imitates the fashionable London man. Therefore, he is not bound to be ridiculed or mocked by the Londoners so he is not a country bumpkin in stark contrast to stereotypical characters of the Restoration comedy of manners plays. On the contrary, Tony is quick enough to turn the tables on himself when he meets Hastings and Marlow coming from the town. As Danziger claims, "whereas country boobies were invariably made the butt of jokes played by witty and polished members of town society, it is Marlow and Hastings, fresh from London, and Mrs. Hardcastle with her townish pretensions who become the butt of Tony Lumpkin's jokes" $(1978,53)$. That is to say, Tony is able to deceive Marlow and Hastings by leading them to his family house as if it was an inn, and his plot enables Kate to unmask Marlow's true nature. Tony also benefits from this plot as he does his best to unite Neville and Hastings. It is again Tony who plots the robbing of Neville's jewels from his mother and plans for the young lovers to escape (III. 366-67). However, Hastings and Marlow ruin his plans by returning the jewels to his mother. Then, he misleads Mrs. Hardcastle who thinks that she is with Neville on the way to aunt Pedigree and frightens the mother who believes that they are in a "frightful place, so far from home" (V. 391). In this comic scene, Tony creates "stage illusion" once more as "[t]he audience know [Mrs. Hardcastle] is being gulled, but if they are to feel the force of her panic (as one should, in farce) they too must share a little in the impression of an unknown, threatening world of quagmires and highwaymen which Tony conjures up out of the most ordinary materials" (Worth 1992, 91). The reason for such illusions lies in Tony's wish to liberate himself from the parental pressure as he cannot directly oppose his mother. Therefore, his antagonism is harmless and triggers comic action in the play.

While Tony struggles to find a way out of his mother's plan through his witty counter-plots, Neville under the guardianship of the Hardcastle family cannot rebel against them. When she is given a chance to flee with Hastings, Neville hesitates to take action, saying and opposing her lover: "My spirits are so sunk with the agitations I have suffered, that I am unable to face any new danger. [. . .] Prudence once more comes to my relief, and I will obey its dictates. In the moment of passion, fortune may be despised, but it ever produces a lasting repentance. I'm resolved to apply to Mr Hardcastle's compassion and justice for redress" (V. 392). This scene shows that "Hastings and Neville underline the sentimental foundations of the play. They have already found one another, try to escape the figure of authority that keeps them separate, but finally conclude that love between two people cannot remain at its happiest when it flies in the face of social convention" (Schmidt 1975, 152). In other words, they pursue romantic love in the marital relationship, but Neville warns Hastings that their love may decrease as long as they cannot comply with the requirements of their society. For this reason, she emphasises the consent of the authoritative figures who act like parental figures by protecting her, whereas the couples in the Restoration comedy of manners engage in intrigues to achieve what they desire. In this regard, in Worth's words, "Constance and Hasting hardly count as true rebels against the system" $(1992,105)$. Their obedience is rewarded in the end when Mr. Hardcastle reveals the strategem of Mrs. Hardcastle to keep Tony under her control by hiding the fact that her son is of age. As soon as this fact is revealed, Tony declares that

you'll see the first use I'll make of my liberty. (Taking Miss Neville's hand.) Witness all men by these presents, that I, Anthony Lumpkin, Esquire, of BLANK place, refuse you, Constantia Neville, spinster, of no place at all, for my true and lawful wife. So Constance Neville may 
marry whom she pleases, and Tony Lumpkin is his own man again (V. 396-97).

While Tony gains authority, he proves his good nature by leading the sensible couple to unite in that he also frees himself from the arranged marriage. In this regard, it can be argued that Tony also looks for a kind of mutual affection in his marriage so he cannot marry a woman that his mother chooses for him as part of her material and maternal concerns.

While Mrs. Hardcastle fails in her strategem, Mr. Hardcastle succeeds in his plan for his daughter Kate's marriage. Indeed, Mr. Hardcastle and Kate have a unique father-daughter relationship. From the beginning of the play, Semiday contends, Mr. Hardcastle is rendered as an "atypical [character] for the late eighteenth-century head of household" $(2015,12)$. He is contended with his simple life in the country by avoiding "vanity and affectation" (I. 333) of the town. Albeit their differences, he does not have any troubles in his marriage with Mrs. Hardcastle. However, his fatherhood is problematic in the sense that he does not fulfil an ideal father role for his step-son whereas the case for Kate is quite different: "Mr. Hardcastle surrounds Kate with all kinds of paternal love and care, while he chooses any opportunity to poke fun at Tony and his mother for her wrong way in raising him" (Shtaywi 1994, 168). He is concerned with the future of his daughter in that the father himself chooses a husband from town for Kate. He praises the man whom he deems suitable of his own daughter, saying: "Depend upon it, child, I'll never controul your choice; but Mr Marlow, whom I have pitched upon, is the son of my old friend, Sir Charles Marlow, of whom you have heard me talk so often. The young gentleman has been bred a scholar, and is designed for an employment in the service of his country. I am told he's a man of an excellent understanding" (I. 336). As an obedient daughter, Kate counts on her father's decision, but she does not hesitate to reveal that she looks for a lover at first place:

Lud, this news of Papa's, puts me all in a flutter. Young, handsome, these he put last; but I put them foremost. Sensible, good-natured; I like all that. But then reserved, and sheepish, that's much against him. Yet can't he be cured of his timidity, by being taught to be proud of his wife? Yes, and can't I-But I vow I'm disposing of the husband, before I have secured the lover (I. 337).

As can be observed, although Kate does not challenge the patriarchal father figure, her expectations from a man do not entirely correspond to what her father favours. For this reason, she is determined to reach a compromise between parental consent and her own desire.

In the portrait of Kate, Evans claims that "Goldsmith creates a new kind of English heroine, who refashions the duped hero's masculinities so that he becomes worthy of her love and esteem" $(2015,34)$. Although Kate appears to be ready for a love adventure, she is fraught with a big problem when her friend Neville informs the young lady of Marlow's peculiar characteristic: "Among women of reputation and virtue, he is the modestest man alive; but his acquaintance give him a very different character among creatures of another stamp" (I. 338). That is to say, Marlow displays a hypocritical behaviour in the company of women in accord with their social rank. On the one hand, he puts on a mask of shyness and modesty among the women of his class. On the other hand, he turns into a debauched person when he feels himself free in his contacts with the lower classes. Therefore, he assumes two distinct manners as "the rake and the man of feeling" (Evans 2015, 34). In the scene where Kate meets Marlow for the first time, it is observed that Marlow acts timidly and remains aloof: 
MISS HARDCASTLE

\section{MARLOW}

MISS HARDCASTLE

MARLOW
(After a pause.) But you have not been wholly an observer, I presume, Sir: The ladies I should hope have employed some part of your addresses. (Relapsing into timidity.) Pardon me, Madam, I - I I- as yet have studied - only - to - deserve them. And that some say is the very worst way to obtain them.

Perhaps so, Madam. But I love to converse only with the more grave and sensible part of the sex. - But I'm afraid I grow tiresome (II. 355).

In the above dialogue, Marlow's manners demonstrate that he acts like a man of feeling who highly respects women in a kind and tactful way (Barker-Benfield 1992, 249). As Kate is aware of Marlow's pretense, she playfully maintains her humorous conversation with him and acts like a female libertine although such witty responses are not expected from this country girl. When left alone, however, she voices her intention to metamorphose Marlow into a man that she will marry: "Yet the fellow, but for his unaccountable bashfulness, is pretty well too. He has good sense, but then so buried in his fears, that it fatigues one more than ignorance. If I could teach him a little confidence, it would be doing somebody that I know of a piece of service" (II. 357). Kate's aim to reveal Marlow's real identity makes her a powerful female character in Goldsmith's play. She is also a witty figure considering the fact that "[w]it, in practice, manifests itself as the ability to dissimulate one's true desires, while simultaneously intuiting the hidden desires of others" (Sussman 2012, 185). Kate, accordingly, takes advantage of Tony's misleading of Marlow into their house since she manages to disguise herself by playing the role of a barmaid. She mentions that "my chief aim is to take my gentleman off his guard, and like an invisible champion of romance examine the giant's force before I offer to combat" (III. 368). It should be noted in this excerpt that Goldsmith uses the rhetoric of a hero of romance in the depiction of Kate's romantic exploit. Therefore, the playwright empowers his female character both in her discursive pattern and her deeds. From this standpoint, there is no doubt that Goldsmith does not offer sexual liberty of the female libertines to Kate, which is criticised as immorality of the genre, but he renders her witty as such figures from the previous period.

Benefitting from the mistakes of the night, Kate works out her witty stratagem by changing clothes to unveil Marlow's true colour. When she appears in the simple clothes of a barmaid, Marlow begins to flirt with her although he cannot even look at Kate in her previous state. Believing that she is the servant, he praises her beauty and attempts to kiss her (III. 369-70). From the vantage point of psychoanalytic theory, Schmidt asserts that "Marlow as the impudent rake and Marlow as reserved and ineffectual suitor" can be evaluated in terms of "the extremes of Id and Super-Ego" $(1975,154)$. According to the Freudian division of the mind, the id is related to the basic instincts beyond man's control which consists of impulsive forces, sexual desires and other passions by serving "the pleasure principle" (Freud 1961, 46). Adversely, the superego is a kind of restrictive control mechanism as it epitomises "every moral restriction, the advocate of a striving towards perfection" (Freud 1964, 67). While Marlow restrains his behaviour under the influence of the superego whenever he is accompanied by the upper class members, he turns into another man in other cases. On this account, it can be argued that Kate functions to balance the id and the superego of Marlow by helping him to find a medium to regulate the opposite demands of these two forces. Therefore, she exercises the ego in Freudian terms in Goldsmith's play. Moreover, Marlow's reversed manners towards the same woman in two different scenes is also evidence of his class-consciousness in that he changes in line with 
the position of the other person. In other words, "[t]he over-sensitive man can become a kind of hypocrite, altering his behaviour too readily to suit the social context" (Donaldson 1986, 173). This attitude can also be traced in his dialogues with Mr. Hardcastle (II. 350; IV. 375) because Marlow assumes that he is the innkeeper. Upon witnessing his rudeness, however, Mr. Hardcastle grumbles about Marlow's personality and questions his choice for his daughter:

What could my old friend Sir Charles mean by recommending his son as the modestest young man in town? To me he appears the most impudent piece of brass that ever spoke with a tongue. He has taken possession of the easy chair by the fire-side already. He took off his boots in the parlour, and desired me to see them taken care of. I'm desirous to know how his impudence affects my daughter (III. 362).

When Mr. Hardcastle later warns his daughter about Marlow, Kate's mission becomes two-fold: “Kate must revise her father's view of Marlow as well as having to enlarge Marlow's vision of his whole self" (Schmidt 1975, 227).

Although Marlow later understands his mistake and realises his illmannered actions at Mr. Hardcastle's house, Kate still appeals to him in her disguise. He tells her that "I mistook your assuiduity for assurance, and your simplicity for allurement. But its over-This house I no more shew my face in" (IV. 378). Kate replies to him saying, "I'm sure I should be sorry to affront any gentleman who has been so polite, and said so many civil things to me. I'm sure I should be sorry (pretending to cry) if he left the family upon my account. I'm sure I should be sorry people said any thing amiss, since I have no fortune but my character" (IV. 378). This false pretence of weeping can be regarded as Goldsmith's mockery of sentimentalism in the play. To further argue, it becomes Kate's weapon to conquer Marlow's heart as he sincerely utters:

By heaven, she weeps. This is the first mark of tenderness I ever had from a modest woman, and it touches me; (to her) Excuse me, my lovely girl, you are the only part of the family I leave with reluctance. But to be plain with you, the difference of our birth, fortune and education, make an honourable connexion impossible; and I can never harbour a thought of seducing simplicity that trusted in my honour, or bringing ruin upon me, whose only fault was being too lovely (IV. 378-79).

That is to say, Kate is able to conquer Marlow's heart by condescending her social position as indicated in the first half of the title, She Stoops to Conquer, as in "stoop," "to bow down, to descend" ("Stoop"). To put it differently, she "commits [. . .] social suicide in her pursuit of her love interest, Marlow" (Semiday 2015, 10) by moving to a lower position in her disguise. However, it is only an illusion that she creates as part of her stratagem for love and marriage. In contrast to Kate, Marlow is honestly willing to stoop because he is a sentimental figure of good nature considering that he is impressed by Kate's "courageous innocence, and conscious virtue" (V. 394). Accordingly, he even offers to cross class boundaries for the sake of his love which can be detected in the following dialogue:

MARLOW I am now determined to stay, Madam, and I have too good an opinion of my father's discernment, when he sees you, to doubt his approbation.

MISS HARDCASTLE No, Mr Marlow, I will not, cannot detain you. Do you think I could suffer a connexion, in which there "is the smallest room for repentance? Do you think I 
would take the mean advantage of a transient passion, to load you with confusion? Do you think I could ever relish that happiness, which was acquired lessening your's?

MARLOW By all that's good, I can have no happiness but what's in your power to Grant me. Nor shall I ever feel repentance, but in not having seen your merits before. I will stay, even contrary to your wishes; and tho' you should persist to shun me, I will make my respectful assiduities atone for the levity of my past conduct (V. 394).

As can be observed, Marlow does not strive for any materialistic concern or purely sexual desire. His sincere feelings hint at the idea of romantic love in this play which corresponds to what the young lovers of the late $18^{\text {th }}$ century looked for in marital relationships. This sense of an emotional tie leads him to think about "breaking away from family control [and] marry for 'love" (Macfarlane 1993, 122). Therefore, "Marlow's growing appreciation of a truly modest woman" (Evans 2011, 60) comes to a climactic point in that Kate's true identity is revealed to Marlow by his father Sir Charles and Mr. Hardcastle, and the lovers are united at the end. This happiness can be attributed to Kate's witty stratagem as her plan enables her to reveal Marlow's good nature which is "already sufficiently well equipped with moral sense and proper delicacy" (Butt 1979, 188). Thus, the mistakes of the night referred to in the second half of Goldsmith's title - The Mistakes of a Night - are exploited by Kate's strong will and correct strategy. The agency of a country girl helps her to find a lover-husband so she achieves the victory through stooping.

On the edge of the analysis of Goldsmith's play, it can be thought that the setting of the play is the country in which immorality and corruption of libertinism does not occur, and the stereotypical characters of Restoration comedy of manners plays are subverted. The playwright mainly deals with the themes of love, marriage and familial relationships in She Stoops to Conquer. More strongly, the play does not deal with the obsession of sexual desires or of cynicism towards love and marriage. This work, unlike earlier plays of this genre, does not question the institution of marriage; on the other hand, it celebrates the idea of love in marital arrangements rather than the achievement of social status or material gain. As the concept of romantic love appears in the second half of the $18^{\text {th }}$ century (Macfarlane 1993, 122-23), young couples insist on marrying those with whom they fall in love. However, they do not challenge the social norms in the play so the stratagem of the play aims to reach a compromise between the demands of the young people and the parental figures. Therefore, Goldsmith puts forward the idea of true love in a way that does not challenge the maintenance of the order in society by portraying the young characters obedience to their parents. 


\section{REFERENCES}

Barker-Benfield G. J. (1992). The Culture of Sensibility: Sex and Society in Eighteenth-Century Britain. Chicago 1992.

Burns E. (1987). Restoration Comedy: Crises of Desire and Identity. London 1987.

Butt J. (1979). The Age of Johnson 1740-1789. Oxford 1979.

Bywaters D. (2009). "Representations of the Interregnum and Restoration in English Drama of the Early 1660s". The Review of English Studies 60/244 (2009) 255-70.

Chernaik W. (1995). Sexual Freedom in Restoration Literature. Cambridge 1995.

Cox J. E. (1969). The Rise of Sentimental Comedy. Springfield 1969.

Danziger M. K. (1978). Oliver Goldsmith and Richard Brinsley Sheridan. New York 1978.

Donaldson I. (1986). "Drama 1710-1780”. Ed. R. Lonsdale, Dryden to Johnson (1986) 161-192. London.

Evans J. (2011). “The Dullissimo Maccaroni': Masculinities in She Stoops to Conquer". Philological Quarterly 90/1 (2011) 45-65.

Evans J. (2015). “Adapting the Stratagem: Goldsmith's She Stoops to Conquer". A Quarterly Journal of Short Articles 28/1 (2015) 34-38.

Freud S. (1961). "The Ego and the Id". Ed. J. Strachey, Trans. A. Strachey, The Standard Edition of the Complete Psychological Works of Sigmund Freud: The Ego and the Id and Other Works. Vol. XIX (1923-1925) (1961) 12-66. London.

Freud S. (1964). "New Introductory Lectures on Psycho-Analysis". Ed. J. Strachey, Trans. A. Strachey, The Standard Edition of the Complete Psychological Works of Sigmund Freud: New Introductory Lectures on Psycho-Analysis and Other Works. Vol. XXII (1932-1936) (1964) 5-182. London.

Goldsmith O. (1969). "An Essay on the Theatre; or, a Comparison between Laughing and Sentimental Comedy". Ed. G. H. Nettleton \& A. E. Case, British Dramatists from Dryden to Sheridan (1969) 751-753. Carbondale.

Goldsmith O. (1993). She Stoops to Conquer, or the Mistakes of a Night. Ed. D. W. Lindsay, The Beggar's Opera and Other Eighteenth-Century Plays (1993) 327-399. London.

Hitchcook T. (1997). English Sexualities, 1700-1800. London 1997.

Keeble N. H. (2002). The Restoration: England in the 1660s. Oxford 1961.

Krutch J. W. (1961). Comedy and Conscience after the Restoration. New York 1961.

Macfarlane A. (1993). Marriage and Love in England 1300-1840. Oxford 1993.

Montgomery F. W. (1966). "The Challenge of Restoration Comedy". Ed. J. Loftis, Restoration Drama: Modern Essays in Criticism (1966) 32-43. New York.

Moody H. R. (1986). "The Meaning of Life and the Meaning of Old Age". Ed. T. R. Cole \& S. A. Gadow, What Does It Mean to Grow Old? Reflections from the Humanities (1986) 9-40. Durham.

Moore W. (2009). "Love and Marriage in $18^{\text {th }}$-Century Britain". Historically Speaking 10/3 (2009) 8-10.

Nettleton G. H. \& Case A. E. (1969). "She Stoops to Conquer; or, the Mistakes of a Night". Ed. G. H. Nettleton \& A. E. Case, British Dramatists from Dryden to Sheridan (1969) 755-756. Carbondale.

Quintana R. (1965). "Goldsmith's Achievement as Dramatist". University of Toronto Quarterly 34/2 (1965) 159-177.

Schmidt R. N. (1975). Uncommon Common Sense: An Intellectual History and Literary Study of Sentimentalism, Oliver Goldsmith and She Stoops to Conquer within the Original British Liberalism of the Third Quarter of the Eighteenth Century. Unpublished Dissertation. University of California, California 1975.

Semiday S. (2015). Mining for Goldsmith: Kate Hardcastle from She Stoops to Conquer. Unpublished MA Thesis. Regent University, London 2015.

Shtaywi A. A. Q. (1994). Courtship and Marriage in Oliver Goldsmith's Major Works. Unpublished Dissertation. Oklahoma State University, Oklahoma 1994.

Simmons E. (1994). "Restoration and $18^{\text {th }}$-Century Drama". Ed. Simmons A Guide to Restoration and Eighteenth Century Literature: 1660-1789 (1994) 39-57. London. 
Stone L. (1979). The Family, Sex and Marriage in England 1500-1800. London 1979.

"Stoop." (1989). The Oxford English Dictionary. Vol. X. Oxford $1989^{2}$.

Sussman C. (2012). Eighteenth-Century English Literature: 1660-1789. Cambridge 2012.

Underwood D. (1957). Etherege and the Seventeenth-Century Comedy of Manners. New Haven 1957.

Wood N. (2011). “Goldsmith's English Malady”. Studies in the Literary Imagination 44/1 (2011) 63-83.

Worth K. (1992). Sheridan and Goldsmith. London 1992. 
